käytetään lukijaystävällisesti. Yksityiskohtaisen kuvauksen vuoksi kirja on osin hakuteoksen kaltainen, mutta monin paikoin sitä voi lukea yleisesityksenäkin. Teos on tieteellisesti arvokas kuvaus muuttuvasta, osin uhanalaisesta suomenruotsalaisesta kielimaisemasta. Pääosaa kirjassa käsitellyistä murteista voi kuunnella niiden nykymuodoissa verkkosivustolla http://www.sls.fi/sv/spara-talet. Sivustolla on myös karttoja murrealueista.

Tandefeltin toimittama Gruppspråk, samspråk, två språk puolestaan muodostaa harkitun kokonaisuuden artikkeleiden järjestystä myöten. Kaikilta osin kirjassa esitelty tutkimus ei ole uutta, mutta näissä tapauksissa tuloksia pyritään suhteuttamaan uuteenkin tutkimukseen. Sopivasti populaarin otteensa ansiosta kirja sopii hyvin kielentutkimuksesta kiinnostuneille lukijoille, muillekin kuin kielitieteilijöille.

$$
\begin{array}{r}
\text { MIKKO KURONEN } \\
\text { etunimi.j.sukunimi@jyu.fi } \\
\text { Kirjoittaja on ruotsin kielen yliopiston- } \\
\text { lehtori Jyväskylän yliopistossa. }
\end{array}
$$

\section{Lähteet}

Kuronen, Mikко 200o: Vokaluttalets akustik $i$ sverigesvenska, finlandssvenska och finska. Studia Philologica Jyväskyläensia 49. Jyväskylä: Jyväskylän yliopisto.

Leinonen, Therese - Henning-LindBLOM, ANnA 2016: Gymnasieelevers åsikter om standardspråk och variation i finlandssvenskan. - Jaana Kolu, Mikko Kuronen \& Åsa Palviainen (toim.), Svenskan i Finland 16 s. 92-107. Jyväskylä: Jyväskylän yliopisto.

Reuter, Mikael 1971: Vokaler i finlandssvenskan. En instrumentell analys och ett försök till systematisering enligt särdrag. - Lars Huldén \& Carl-Eric Thors (toim.), Festskrift till Olav Ahlbäck 28.3.1971 s. 240-249. Studier i nordisk filologi 58. Skrifter utgivna av Svenska litteratursällskapet i Finland 446. Helsingfors: Svenska litteratursällskapet i Finland.

Selenius, Евв 1972: Västnyländsk ordaccent. Studier i nordisk filologi 59. Skrifter utgivna av Svenska litteratursällskapet i Finland 451. Helsingfors: Svenska litteratursällskapet i Finland.

\title{
Suomenruotsi painettuna, koulussa ja yhteiskunnassa
}

\author{
Marika Tandefelt (toim.): Språk i prosa \\ och press. Svenskan i Finland - i dag och i \\ går II:1. Helsingfors: Svenska litteratursäll- \\ skapet i Finland 2017. 242 s. ISBN 978-951- \\ 583-362-4.
}

Marika Tandefelt (toim.): Språk i skola och samhälle. Svenskan i Finland - i dag och i går Il:2. Helsingfors: Svenska litteratursällskapet i Finland 2017. 207 s. ISBN 978-951-583-363-1.
Marika Tandefelt on työryhmineen laatinut laajan katselmuksen Suomessa käytettävästä ruotsin kielestä. Työn tuloksena on syntynyt tähän mennessä neliosainen kirjasarja Svenskan i Finland - i dag och i går. Tulossa on vielä kaksi osaa, joiden arvioidaan ilmestyvän 2019. Työ on kestänyt ensimmäisistä hankesuunnitelmista lähtien kaikkiaan yli kymmenen vuotta, ja siihen on osallistunut 30 tutkijaa. Hankkeessa on hyödynnetty vanhoja arkisto- 
aineistoja mutta kerätty runsaasti myös uutta aineistoa. Teossarjassa on mukana sekä uusia alkuperäisartikkeleita että koosteita aiemmasta tutkimuksesta.

Tällaisen laajan urakan toteuttaminen vaatii tieteellistä ja tiedepoliittista suunnittelua sekä riittävää ja pitkäkestoista rahoitusta hankkeelle. Onkin siis puolensa myös sillä, että tutkimusrahoitusta jaetaan ohjelmille ja laajoille hankkeille, ei vain yksilöiden omille projekteille. Tätä hanketta ovat tukeneet monet kotimaiset ja ruotsalaiset rahoittajat, muiden muassa Svenska litteratursällskapet, Svenska Akademien ja Riksbankens Jubileumsfond. Yhteistyökumppaneina ovat olleet Kotimaisten kielten (tutkimus)keskus ja Göteborgin yliopisto, jossa on suuri ruotsin kielipankki Språkbanken.

Julkaisusarjan kaksi ensimmäistä osaa ilmestyivät vuonna 2015, ja ne käsittelevät puhuttua kieltä ja alueellista variaatiota (Ivars 2015; Tandefelt toim. 2015). Näistä on erillinen esittely tässä samassa lehdessä (ks. Kuronen). Tässä arviossa esittelen vuonna 2017 ilmestyneet Tandefeltin toimittamat osat Språk i prosa och press ja Språk i skola och samhälle. Ne käsittelevät kirjoitettua kieltä. Molemmissa teoksissa on johdannon lisäksi yhdeksän artikkelia, mikä tarkoittaa, että näkökulmien ja työn määrää on tietoisesti rajattu, sillä kielen ja yhteiskunnan suhteesta, samoin kuin kirjoitetusta kielestä ja tekstilajeista, löytyisi helposti aineksia kymmeniin artikkeleihin. Tärkeitä aiheita on siis jäänyt pois.

Teossarja on ilmiselvästi tarkoitettu myös muille kuin tutkijoille. Artikkelit ovat lyhyitä, eikä sisältöä ole jaoteltu moniin hierarkkisiin portaisiin. Lähdeviitteet on osoitettu loppuviitteillä, ja viitteisiin on koottu hyödyllistä lisätietoa kirjallisuudesta laajemminkin. Artikkelit menevät suoraan asiaan ilman termitai teoriaselityksiä, mikä tarkoittaa myös sitä, että kielestä ja teksteistä puhutaan yleiskielestä tutuin ilmauksin. Esimerkiksi oppikirjojen abstraktin sanaston kerrotaan olevan yhteydessä substantiivitautiin ja kääntäjän sanotaan joutuvan stilisoimaan lähtötekstejä. Tämä laskee hiukan tieteellistä kunnianhimoa ja käyttökelpoisuutta mutta palvelee niitä lukijoita, jotka eivät toimi kielitieteen ydinaloilla.

\section{Kirjoitettukin suomenruotsi varioi alueellisesti}

Teossarjan osa Språk i prosa och press käsittelee ennen muuta julkaistuja tekstejä tiedotusvälineiden kieltä ja kaunokirjallisuutta sekä niiden kielenhuoltoa. Vaikka sarjan nimessä on sanat "i dag och i går", käsittelevät tässä tarkasteltavat teokset enimmäkseen nykypäivän kieltä ja kielenhuoltoa. Parin vuosikymmenen takainen aineistokin on kielen elämässä vielä päivänkohtaista. Tosin tähän päivään ei ole tultu ilman historiaa, joten nykyisistä kielikäsityksistä ja ristiriidoista voi lukea myös menneiden aikojen tulkintoja. Silti pieni systemaattinen aikaperspektiivin laajennus olisi taustoittanut monissa artikkeleissa nykyhetkeä.

Teoksen kirjoittajat ovat yhtä lukuun ottamatta kielentutkijoita ja -huoltajia. Artikkeleista neljä on Tandefeltin omia artikkeleita, samoin johdanto, ja yhdessä artikkelissa hän on mukana kirjoittajana. Toinen puoli jää muiden kirjoittajien vastuulle. Teoksen artikkeleista monet käsittelevät kirjoitetun suomenruotsin tietoista kielenhuoltoa ja kielen kehittämisen kysymyksiä, ja kielenhuollollinen perusvire on niissäkin artikkeleissa, joiden luonne on kuvaileva. Kirjoittajat päätyvät tuon tuosta pohtimaan ilmausten hyvyyttä ja hyväksyttävyyttä tai kielenhuollon merkitystä. Teoksessa käsitellään myös kieliasenteita, kaunokirjallisuuden kieltä sekä kustantajien toimintaa. Sääli, että tietokirjallisuus ja sen tarvitsema kielenhuolto ja termityö ovat jääneet kokoelman ulkopuolelle. Neljä artikkelia keskittyy tiedotusvälineiden kieleen. 
Kirjan avausartikkelissa "Finlandismer i skriven finlandssvenska" Charlotta af Hällström-Reijonen, Mikael Reuter ja Tandefelt pohtivat finlandismeja. Ilmiö kyllä tunnetaan, ja siitä on monilla mielipiteitä, mutta tutkijan on vaikea määritellä sitä kattavasti. Se, mikä suomenruotsissa tuntuu suomalaisuudelta, saattaakin olla jonkin kolmannen kielen vaikutusta (esim. venäjän, latinan tai englannin). Suomen kielen vaikutteita voi olla sanastossa, taivutuksessa, merkityksessä tai lauserakenteessa. Taustalla voi olla kulttuurisyitä, esimerkiksi suomenruotsissa tarvitaan täkäläisen koulutuksen mukaisia ammattinimikkeitä (diplomingenjör, munhygienist). Vaikka kirjoittajat vakuuttavat, ettei finlandismi ole virhe, he kannustavat valitsemaan omaperäisen sanan, jos sellainen on: ei siis kokko vaan midsommarbrasa. Sen sijaan esimerkiksi talko on aivan sopiva, koska sille ei ole Ruotsissakaan omaa vastinetta.

Finlandismit tulevat tarkempaan tarkasteluun af Hällström-Reijosen sanomalehtikieltä käsittelevässä artikkelissa "Dagstidningsfinlandismer". Artikkelista käy ilmi, että finlandismien määrä ja luonne vaihtelevat alueittain. Suomenruotsiksi kirjoitetaan esimerkiksi paketbil, sist och slutligen, beslöt, morgonmål (ruotsinruotsiksi skåpbil, i själva verket, beslutade, frukost). Parin vuosikymmenen aikana finlandismien määrä näyttäisi kuitenkin vähentyneen, minkä kirjoittaja tulkitsee johtuvan kielenhuollosta ja kieliasenteiden muutoksesta. Olisi mielenkiintoista, jos tätä havaintoa voisi pohtia myös pitäen silmällä muuta kirjoitetun kielen muutosta ja kielenhuollon vaikutusta. Merkitystä lienee silläkin, minkäkielisiä haastateltavat ja muut tietolähteet ovat.

Suomenruotsalaisen kaunokirjallisuuden kysymyksiä tarkastelee kahdessa artikkelissaan Tandefelt. Ensimmäinen artikkeli "Språkval i finlandssvensk skönlitterär prosa" on laaja katsaus monien kirjallisuudentutkijoiden tekemiin tutki- muksiin. Tandefelt korostaa, ettei ole yhtä suomenruotsalaista kirjallisuutta, kirjailijaa tai kirjallista esitystapaa. Tämän osoittamiseksi hän kuvaa erityyppisiä kirjailijaprofilieja ja kielivalintoja. Kiinnostava ilmiö on kielten ja kielimuotojen yhdistäminen. Esimerkiksi Kjell Westö voi käyttää kirjoissaan suomea ruotsin seassa, sillä suomenruotsalaisen lukijan voi olettaa osaavan lukea suomea vaivatta. Mutta entäpä, kun teos käännetään suomeksi? Kääntäjän päänvaiva lisääntyy entisestään, kun käännöksellä on välitettävä sekä aluemurteita että eri-ikäisten ja eritaustaisten ihmisten sisäistämiä kielinormeja.

Kustantamoiden toimintaa käsittelevässä artikkelissaan "Författaren, förläggaren och språket" Tandefelt nostaa esiin kielen plurisentrisyyden eli sen, että kielen standardimuodot kehittyvät useassa keskuksessa - usean valtion alueella -, ja vertaa ruotsinkielisten kustantamoiden toimintaa muun muassa hollanninkielisiin. Hollannin kieltä käytetään sekä Belgiassa että Alankomaissa ja kielen standardimuoto määräytyy kahdessa kulttuurissa kuten ruotsin kielenkin. Artikkelissa on lisäksi hyödynnetty 30 suomenruotsalaisen kirjailijan haastatteluja.

Artikkelissaan "Svenskspråkiga medier och finlandssvenska medievanor" viestinnäntutkija László Vincze kuvailee suomenruotsalaista mediamaisemaa. Hän esittelee tilastotietoja radio- ja televisiokanavien sekä lehtien määristä ja levikeistä. Olisi ollut hienoa, jos käytössä olisi ollut aikasarjoja edes 50 vuoden ajalta; nyt luvut kertovat lähinnä tämän päivän tilanteesta, ja vain lehtien levikkiä koskevat lukusarjat kattavat edes tämän vuosituhannen. Vaikka alueellista vaihtelua on, ruotsinkieliset valitsevat radiokanavat ja sanomalehdet mieluiten kielen perusteella eli suosien ruotsinkielisiä, mutta televisiota voi katsoa suomeksikin.

Anna Maria Gustafsson tarkastelee artikkelissaan "Den finlandssvenska journalistens språkliga vardag" suomenruot- 
salaisen toimittajan journalistista kielimaisemaa ja journalistien kielenhuoltoa. Kielimaiseman kuvaus perustuu kyselytutkimukseen, jossa vastaajat muun muassa arvioivat niin työssä kuin vapaaaikana käyttämiensä kielten määriä. Toimittajien kielenhuoltokäytäntöjä selvitettiin niin ikään kyselyllä, jossa vastaajat saivat kommentoida kieltä ja kielenhuoltoa sekä kuvailla kielikäsityksiään. Mielenkiintoinen tulos on esimerkiksi se, että toimittajien työ- ja vapaa-ajan elämä on ruotsinkielisempää kuin heidän lukijoidensa ja kuulijoidensa.

Gustafssonin toinen artikkeli "De finlandssvenska journalisterna och språkvården" kuvaa, miten suomenruotsalaisen median kielenhuoltokäytännöt ovat kehittyneet. Muiden Pohjoismaiden tapaan Kotimaisten kielten tutkimuskeskus alkoi lähettää toimituksiin kielenhuoltokirjeitä 1980-luvulla. Pian toiminta kasvoi laajaksi ja systemaattiseksi, ja nyt kieliasiantuntijoiden järjestämä kielenhuolto kattaa koko mediakentän ja käytössä on sanakirjoja, hakuteoksia, ohjekirjeitä - kaikkia näitä toki sekä painettuina että sähköisinä. Apuneuvoista paras on kuitenkin kollega: vaivaton, lähellä ja nopea. Artikkeli ei valaise tarkemmin, millaisiin asioihin toimittajat tarvitsevat neuvoja. Sen sijaan se käy hyvin selväksi, että toimitukset ja kustantamot ylintä johtoa myöten ovat sitoutuneet kielen ja tekstien huoltoon.

Median kieltä tarkastellaan myös lukijoiden näkökulmasta. Tandefelt on koonnut toimitusten saamista spontaaneista kielipalautteista katsauksen artikkeliin "Läsare tycker till". Palautteet voivat olla yleisiä tyyliin "onpas huonoa kieltä" tai hyvin tarkkarajaisia: "Miksi sanotaan ruotsalaisittain jultomte, kun oikeasti pitäisi sanoa julgubbe!"

Kokoelman päätösartikkelissa "Forskare säger sitt" Tandefelt käy läpi suomenruotsalaisen lehtikielen kehitystä sadan vuoden ajalta. Tämä on kokoelman ainoa kielenkäytön historiaa systemaattisesti valottava artikkeli. Tandefelt on koonnut yhteen monien tutkijoiden analyysejä lehtikielestä, finlandismeista ja kieliasenteista. Finlandismien rinnalle on ilmaantunut yhä kasvava joukko anglismeja. Päätössanoissa tutkija antaa lohdullisen kuvan toimittajien työstä: ammattikirjoittaja osaa valita ilmaisuvälineensä ja käyttää niitä.

\section{Kieli koulussa ja yhteiskunnassa}

Teossarjan osassa Språk i skola och i samhälle käsitellään kieltä organisaatioiden kontekstissa. Kirjoittajien joukossa on kielitieteen ja kielenhuollon ohella asiantuntemusta monelta alalta: juridiikasta, kasvatustieteestä, kansainvälisestä yritystoiminnasta, vieraiden kielten didaktiikasta ja markkinoinnista.

Johdannon lisäksi teoksessa on yhdeksän artikkelia. Niissä kuvataan neljää eri osa-aluetta: koulu, viranomaistyö, kääntäminen ja kieliasiantuntijuus sekä elinkeinoelämä. Koulua koskevista artikkeleista ensimmäinen käsittelee kirjoittamisen opetusta, toinen oppikirjoja. Viranomaiskieltä ja lakitekstejä tarkastellaan kumpaakin omissa artikkeleissaan. Kääntämiselle ja kieliasiantuntijuudelle on molemmille omat artikkelinsa. Kolme artikkelia käsittelee elinkeinoelämää kukin omasta näkökulmastaan: kielivalintoja, englanninkielistymistä ja asiakaspalvelun kieltä.Vaikka aiheita on paljon, jää kuva yhteiskunnasta kapeaksi, mutta rajansa kaikella; kielikylpyä, opettajankoulutusta, akateemista maailmaa, kielellisiä oikeuksia, julkisten organisaatioiden kielivelvoitteita ja monia muita kielen ja yhteiskunnan rajapintoja voi käsitellä muissakin yhteyksissä. Alkupään artikkelit kuvaavat selvästi suomenruotsalaisia kielitilanteita, joissa julkisella vallalla on mahdollisuus ohjailla kieltä. Kokoelman loppupäätä kohti tarkastelu muuttuu globaalimmaksi, monikielisemmäksi ja vaikeammin säänneltäväksi. 
Anna Slotte ja Liselott Forsman kuvaavat artikkelissaan "Skriva av och skriva eget. Samtal om skrivande i den svenskspråkiga skolan i Finland" kirjoittamisen opetusta ja sitä, miten opettaja keskustelee oppilaiden kanssa teksteistä. Artikkeli voisi olla muuten yleinen kirjoittamisen pedagogiikkaa käsittelevä artikkeli, mutta teossarjan juonen mukaisesti siinäkin tulee vastaan suomenruotsin erityispiirre: opettaja kohtaa jatkuvasti tilanteita, joissa oppilas osaa ilmaista asian suomeksi mutta ei löydä sille ruotsinkielistä vastinetta.

Oppimateriaalien tarkastamista käsittelevä Monica Äikkään artikkeli "Språkgranskning av finlandssvenska läromedel" on samoin yleisellä tasolla liikkuvaa kuvausta tekstien ymmärrettävyydestä, abstraktiotasosta ja koheesiosta. Äikäs kytkee aiheen kuitenkin suomenruotsalaisten oppikirjojen erityispiirteisiin, sillä suuri osa kirjoista on suomesta käännettyjä. Kääntämisen ja kielenhuollon lisäksi tarvitaan termien tarkistusta mutta myös lokalisointia; lähtöteksteissä voidaan viitata suomenkielisiin teksteihin tai suomenkieliselle kulttuurille tuttuihin esimerkkeihin, mutta käännetyssä oppikirjassa tarvitaan suomenruotsalaiset ilmaukset.

Artikkelissaan "Lagspråket" Sten Palmgren kuvaa lakikielen olemusta, kehitystä ja muutosta. Lakikielen on oltava ymmärrettävää, mutta saako käännetty kieli olla ymmärrettävämpää kuin alkuperäinen? Digitaalisuus tuo paljon hyvää ja helpotusta myös lainsäädäntötyöhön, mutta katkelmien kopiointi saattaa osoittautua petollisen helpoksi, ja moni yksityiskohta jää tarkistamatta ja muokkaamatta.

Jannika Lassus kuvaa artikkelissaan "Svenskt myndighetsspråk i Finland" suomenruotsalaisen viranomaiskielen piirteitä. Toisaalta viranomaisten tekstien tulee noudattaa suomalaista hallintokulttuuria ja olla etäisiä ja vakavia. Toisaalta Ruotsista löytyisi hyviä malleja kie- len selkeyttämiseen ja tekstien asiakaslähtöisyyteen. Artikkeli on hyödyllinen yleisjohdanto viranomaiskieleen, ja lukija jää odottamaan tarkempia kuvauksia erilaisista asiakaspalvelutilanteista ja erilaisten tekstien ominaislaadusta.

Toisessa artikkelissaan "Översättning till svenska i Finland" Lassus kuvaa kääntäjän työskentelyä sekä julkisessa että yksityisessä organisaatiossa. Artikkeli on jälleen hyvä yleisjohdanto kääntämiseen, erilaisten tekstien vaatimuksiin ja kääntäjän työkaluihin. Yllättävää on, että kääntäjät turvautuvat mieluummin yleisiin internethakuihin kuin huolellisesti laadittuihin kielipankkien aineistoihin. Tämä antaa aiheen arvioida vaivalla rakennettujen pankkien merkitystä ennemmin kuin kääntäjien toimintaa.

Rune Skogbergin artikkeli "Att vara språkexpert i ett företag" käsittelee kielenhuoltajan työtä yritysmaailmassa. Hän kuvaa kielenhuoltajan ammattitaitoa; artikkelissa on luettelo noin 30 eri tehtävään suunnatusta tekstilajista, joiden parissa kieliammattilaisen on osattava toimia. Tämä koskee jokaista kielenhuoltajaa, mutta suomenruotsalaisen kieliasiantuntijan on osattava myös kääntää ja tarkistaa vastineita.

Wilhelm Barner-Rasmussen ja May Lönnholm kysyvät artikkelissaan "Svenskan i finländskt näringsliv - till nytta eller till besvär?" hieman ironisesti, onko ruotsin kielestä hyötyä vai haittaa elinkeinoelämässä. Artikkelin aineistona on yritysten johtotasolle tehty kysely ruotsin kielen käytöstä. Aineiston perusteella kirjoittajat osoittavat ruotsin osaamisen hyötyjä ja puutteellisen kielitaidon haittoja. Uralla etenemiseen kielitaidolla on vaikutusta. Loppuluku tiivistää asian pidättyväisesti: ei ruotsia ole pakko osata, mutta on siitä paljon etua.

Barner-Rasmussen lähtee omassa, englanninkielistymistä koskevassa artikkelissaan "När valet står mellan engelska och svenska" liikkeelle siitä, että eng- 
lannin kieli on entistä vahvempi ja yleisempi. Mitä virkaa siis on ruotsilla (tai suomella!) Ruotsin ja Suomen keskinäisissä kauppayhteyksissä? Hän pohtii myös tulevaisuudennäkymiä: miten käy, kun sodanjälkeinen suomenkielinen sukupolvi jää eläkkeelle eivätkä uudet sukupolvet ole motivoituneita puhumaan ruotsia? Kysymys on relevantti, mutta Barner-Rasmussenin argumentti kouluikäisten kiinnostuksen puutteesta ei vakuuta. Olisikin tarpeen katsoa, miten yliopistoissa suhtaudutaan kielten opiskeluun. Jää myös pohdittavaksi, missä määrin on kyse yksilöiden valinnoista ja missä määrin organisaation omasta monikielisyyttä tukevasta kulttuurista.

Kokoelman päättää Jonas Holmqvistin artikkeli "Vad vill den finlandssvenska kunden? Om företagens språkval och om kundbeteende", joka pohtii asiakaspalvelun kieltä. Holmqvist huomauttaa aiheellisesti, että kielilait eivät koske yksityistä sektoria ja että kaksikielisyyttä on ylipäätään tarkasteltu liiaksi viranomaisnäkökulmasta. Hän laventaa näkökulman yhä lisääntyvään monikielistymiseen.

\section{Sopii johdannoksi, ajantasaistukseksi ja syvennykseksi}

Sekä Språk i prosa och press että Språk i skola och samhälle ovat toimivia kokonaisuuksia: artikkelit ovat järjestään tasavahvuisia ja toisiaan täydentäviä. Erinomaista on myös fokuksen tarkkuus, sillä teosten teemoista, kuten kääntämisestä, kielitaidosta ja tekstinhuollosta, nousee aina esiin jokin suomenruotsalainen erityispiirre. Suomenruotsalainen voi nähdä monet asiat toisin. Hän voi käyttää kahta kieltä rinnakkain, peilata käännöstä alkutekstiin, ottaa mallia milloin Ruotsista, milloin Suomesta ja niin edelleen.
Tai sitten hän voi luopua joko pakosta tai omasta aloitteestaan oman äidinkielensä käytöstä.

Kokoelmien artikkelit ovat hyvin toimitettuja, ja ne tarjoavat myös aloittelevalle kielentutkijalle ja -huoltajalle hyödyllisiä johdatteluja kieleen ylipäätään, suomenruotsiin erityisesti ja jossain määrin myös Suomen kielitilanteeseen. Laajojen lähdeluetteloiden avulla pääsee aiheisiin syvemmälle. Kannustaisinkin jo ensimmäisen vuoden suomen ja ruotsin kielen opiskelijoita lukemaan teokset. $\mathrm{Ne}$ sopivat myös median, hallinnon ja juridiikan opiskelijoille. Luonnollisesti teoksissa on antia kokeneemmillekin lukijoille ja urallaan edenneille ammattilaisille; erityisesti uudet tilastot ja kyselyaineistot valaisevat suomenruotsin kokonaiskuvaa. Teossarja täydentyy vielä kahdella kirjoitetun kielen historiaa käsittelevällä osalla. Senkin jälkeen sarja saisi jatkua, sillä käsittelemättä jäävät muun muassa sosiaalinen media, digitaalisuus ja verkkomaailma.

PirJo HiIdENMAa etunimi.sukunimi@helsinki.fi

Kirjoittaja on tietokirjallisuuden ja tietokirjoittamisen tutkimuksen professori Helsingin yliopistossa.

\section{Lähteet}

IVARs, Ann-Marie 2015: Dialekter och småstadsspråk. Svenskan i Finland - i dag och i går I:2. Helsingfors: Svenska litteratursällskapet i Finland.

Tandefelt, Marika (toim.) 2015: Gruppspråk, samspråk, två språk. Svenskan i Finland - i dag och i går I:1. Helsingfors: Svenska litteratursällskapet i Finland. 